\title{
Impact and control of anthropogenic pollution on the ecosystem - A review
}

\author{
Ngozi H. Arihilam* and E. C. Arihilam \\ Akanu Ibiam Federal Polytechnic Unwana, Ebonyi State, Nigeria. \\ ${ }^{*}$ Corresponding author. Email: ngadagab@gmail.com
}

Copyright @ 2019 Arihilam and Arihilam. This article remains permanently open access under the terms of the Creative Commons Attribution License 4.0, which permits unrestricted use, distribution, and reproduction in any medium, provided the original work is properly cited.

Received 12th May, 2019; Accepted 10th June 2019

\begin{abstract}
An ecosystem borders on overall complex network of interconnections between the environments within a habitat. To make the ecosystem substantially habitable for both plants and animals, contaminations into the natural environment that could result to adverse changes to it must not be introduced. Human activities can influence nature generally and, on an environment, the change can be overwhelming giving the ravaging effects of present-day climate change for instance. Among the major threats of environmental problems that disrupt the natural equilibrium is the reckless discharge of pollutants generated from industrial activities. This paper highlights the character and impact of man-made environmental pollutions and suggest ways to combat anthropogenic pollution in our environment.
\end{abstract}

Keywords: Contaminants, ecosystem, environment, ozone depletion, potential trace elements.

\section{INTRODUCTION}

Anthropogenic contamination is a form of pollution produced directly by human activities, such as the burning of fossil fuels, rather than by such processes as respiration and decay. Sources of potential harmful trace elements (PHTEs) are mainly due to high-temperature combustion activities resulting in volatilization of trace elements or their release in the form of very fine substance enclosed under pressure and released as a fine spray by means of a propellant gas. These are obvious anthropogenic pollutants that impact negatively on an ecosystem. Evidence suggests that the release of these pollutants into the atmosphere is among the most important factors responsible for most air borne diseases among plants and animals. Recent developments in climate change have highlighted the need for the world at large to concertedly deal with its root cause as the entire world is under threat. The world's climate, seasons and times are gradually changing. The rainfall and glacier conditions are progressively being eroded leading to flooding and unpredictable happenings in the weather conditions (Pielke, 2013).

An ecosystem is the natural habitat on which living beings depend and by which they affect and are affected
(Soykan and Atasoy, 2006). A considerable amount of literature has been published on the ecosystem as a habitant where living things interact with each other. For example, Genc et al. (2016) described the environment as a large swath of areas and constitutes a habitat where all the living beings are in interaction with each other. The environment has also been described as a biological, physical, social, economic and cultural habitat in which the living beings maintain their relationships throughout their lives and are in mutual interaction (Gokmen, 2011:38). For this reason, changes of the environment through various interventions affect the living beings sharing that environment.

Although the importance of the environment for all living beings cannot be over-emphasized, it is naturally subject to increasing pollution and destruction in line with rapid industrial and technological development. Moreover, the environment provides the natural resources for addressing the raw material needs. But due to the ever-increasing generation of industrial and other wastes resulting from the processing of these raw materials, the unintentional acts of humans end up damaging the environment. Currently, however, environmental problems cause grave conse- 
quences and pose a major threat to the lives of all the creatures living in it (Secgin et al., 2010).

The impact of man-made environmental pollution creates problems that arise as a result of the negative consequences felt by living beings and affect them in negative ways. These could be enumerated as; rapid population growth and housing needs, energy issues, desertification and drought, destruction of forests, erosion, mudslides, floods, avalanches, extinction of species, air pollution, water pollution, soil pollution, global warming etc (Commoner, 2016).

However, these are a few of the major environmental problems that threaten the future of the world and thereby set agenda for countries around the world. Rapid population growth, unplanned urbanisation and irresponsible waste discharge pollute the environmental elements such as air, water and soil; while the squandering of natural resources and lack of education accelerate the disruption of the natural equilibrium (Hardoy and Satterthwaite, 1991).

Anthropogenic pollution can take many forms, but they can be grouped into the air pollution, the water pollution, and soil pollution, the electromagnetic pollution (radiation waist) and even noise pollution. These have the potential to contribute to health problems and a lower quality of life (Espinoza, 2015) with major disruptions and can as well have effects on wild life and ecosystems. In this paper, the impact of anthropogenic pollution on the environment and the ways to combat it is discussed.

\section{CHARACTER OF THE IMPACT OF ANTHROPOGENIC POLLUTION ON THE ENVIRONMENT}

The most important characteristic of environmental problems is that they can be global in terms of their consequences, not local. The consequences of the environmental issues are such that, they affect everybody regardless of their religion, language, race, age, gender, wealth, profession, social class and intellectual capacity (Erten, 2005). Environmental issues have become a concern for the whole world and are increasingly being included in the activities and agreements of international organisations (Genc et al 2016). The reason why environmental issues have become such an encircling hazard for the world boils down to peoples' unawareness of the environmental issues and their irresponsible and cruel attitude towards nature for their own selfish gains. Global warming, the greenhouse effect, ozone depletion, destruction of rain forests, disruption of the natural equilibrium, air and water pollution are some of the most prominent examples of the global environmental issues (Tuna, 2011). Moreover, noise pollution, erosion, desertification, water, air and soil pollution cause disruption of the natural harmony and bring about a myriad of issues consequently.

The responsibility of humans regarding the dispersion of aerosols and PHTEs by anthropogenic activities is undeniable, but mankind also holds a strong responsibility in the intensification of natural dispersal processes (Alex, 2006). For example, the burning of biomass, i.e., forest fires, have been occurring as a part of plant development and ecological renewal for more than 400 million years, yet these fires are now mainly driven and controlled by humans (Demirbas and Pektas, 2009). Similarly, desertification of semi-arid lands and the intensification of agriculture on bare soil also help to accelerate the natural suspension of dust (Keinath, 2004), and thus also the dispersal of PHTEs.

\section{Air pollution and its impact on the environment}

The major single source of air pollutants is the combustion of fossil fuels (coal, oil, and gas) to run industrial machines and generate electricity. All anthropogenic pollutants can be traced to some extent to this source. Sulphur dioxide, oxides of nitrogen, and carbon monoxide are all primary pollutants of the air. Carbon dioxide traps heat. Without it in the atmosphere, the Earth would be a barren, frozen wasteland. Researches have shown that the levels of $\mathrm{CO}_{2}$ are going up. The output of $\mathrm{CO}_{2}$ by industrialization and other human activities are also rising (Slavikova, 2018).

Examples of secondary pollutant include ozone, which is formed when hydrocarbons $(H C)$ and nitrogen oxides $\left(N O_{x}\right)$ combine in the presence of sunlight; $\left(N O_{2}\right)$ which is formed as (NO) combines with oxygen in the air; and acid rain, which is formed when sulphur dioxide or nitrogen oxides react with water.

Considering an ecosystem where erosion or dust emission is predominant, without any underlying hightemperature process, emissions tend to be much more localized (e.g. mining activities). Largely speaking, the impact of anthropogenic pollution can be categorized into the following different sources/activities (Pacyna and Pacyna, 2001):

1. Energy production by combustion: the dominating anthropogenic source of PHTEs emission, entailing burning of wood, coal, and oil ( $\mathrm{As}, \mathrm{Cu}, \mathrm{Hg}, \mathrm{Ni}, \mathrm{Pb}$, Se, and $Z n$ ), (Ana et al., 2012).

2. The metallurgical industry: emission of dust near the extraction and point of exploitation, high-temperature processing of ores emits aerosols rich in trace elements $(\mathrm{Cu}, \mathrm{Ni}, \mathrm{Pb}$, and $\mathrm{Zn})$. The proportion of individual elements emitted in the aerosols depends on the type of ore processed.

3. Other industrial processes: high-temperature processing and manufacturing ( $\mathrm{As}, \mathrm{Cr}, \mathrm{Cu}, \mathrm{Ni}, \mathrm{Pb}$, and $\mathrm{Zn})$.

4. Transport: road traffic (Cu, $\mathrm{Fe}, \mathrm{Ni}, \mathrm{Pb}$, and $\mathrm{Zn}$ ), erosion of brake pads $(\mathrm{Cu}$,$) , erosion of train rails (\mathrm{Cu})$.

5. Waste treatment: incineration of household waste $(\mathrm{Cr}$, $\mathrm{Cu}, \mathrm{Ni}, \mathrm{Pb}$, and $\mathrm{Zn}$ ). 


\section{Water pollution and its impact on the environment}

Water is where life began and why life continues, but it is also the world's most threatened essential resource. In addition to the accelerating climatic-driven threat of drought, where water sources all over the world face the threat of potentially drying up as the warming climate accelerates, water is becoming increasingly polluted every year. Water pollution affects drinking water, rivers, lakes and oceans all over the world. This consequently harms human health, wildlife and the natural environment (Inyinbor et al 2018).

Water pollution also includes any contamination of water with chemicals or other foreign substances, such as fertilizers and pesticides/insecticides/herbicides from agricultural runoff, sewage and food processing waste, lead, mercury and other heavy metals, chemical wastes from industrial discharges, and chemical contamination from hazardous waste sites, that are detrimental to human, plant or animal health that enters water bodies as lakes, rivers, ponds, etc (Reduce Water Pollution, 2016).

Water-borne navigation also causes emissions of carbon dioxide $\left(\mathrm{CO}_{2}\right)$, methane $\left(\mathrm{CH}_{4}\right)$, nitrous oxide $\left(\mathrm{N}_{2} \mathrm{O}\right)$, as well as carbon monoxide (CO), non-methane volatile organic compounds $\left(\mathrm{NMVOC}_{s}\right)$, sulphur dioxide $\left(\mathrm{SO}_{2}\right)$, particulate matter $(P M)$ and oxides of nitrogen $\left(N O_{x}\right)$ (Reduce Water Pollution 2016). Polluted and unsafe water is the leading cause of sickness and death with half of the world's hospital beds filled with people suffering from water-related illnesses.

The sea began receiving radioactive waste from anthropogenic sources way back in 1946 (Reduced Water Pollution, 2016), in a rather unregulated way in the first decades. Both national and international regulations controlling disposals have now slowly come into force. Considerable amounts are still being discharged regularly from nuclear industries and the practice of using the sea as a suitable wastebasket is likely to continue forever. In 1994 an international total prohibition on radioactive waste disposal at sea came into force, but the huge amount of solid radioactive waste that has already been dumped is being gradually released to the water masses (Steele et al., 2008).

Compared to other wastes disposed of at sea, the amount of radioactive waste by weight is rather little. However, contrary to most of the 'ordinary' wastes in the sea, detectable amounts of anthropogenic radioactivity are found in all parts of the world oceans and will continue to contaminate the sea for many thousands of years to come (Steele et al., 2008). This means that anthropogenic radioactive material has become an extra chronic radiation burden for marine organisms. In addition, the release of natural occurring radionuclide from offshore oil and gas production will gradually increase the levels of radium with a possible, at present unknown, effect.

However, marine food is not, and probably never will be, contaminated at a level that represents any danger to consumers. The ocean has always received debris from human activities and has a potential for receiving much more and thereby help to solve the waste disposal problems of humans. But as soon as a waste product is released and diluted in the sea it is almost impossible to retrieve. Therefore, in principal, no waste should be disposed of in the sea without clear documentation that it will never create any damage to the marine environment and its living resources. This means that with present knowledge, no radioactive wastes should be allowed to be released into the sea.

For countries in Africa and other third world nations that hardly generate these radio-active substances, managements and disposal of these toxic wastes often erroneously found around their territorial waters and environment pose a huge problem.

\section{Soil pollution and its impact on the environment}

Well-known anthropogenic sources of potential trace elements (PTEs) and organic pollutants that cause widespread emission toward the soil ecosystem are in mining and smelting; fossil fuel combustion; application of fertilizers, fungicides, and other soil amendments like compost and sewage sludge; waste disposal of industries (notably metallurgical, electronics, and chemical); emission from traffic; and waste incineration. Of these, management of wastes, are particularly important sources of soil chemical pollutants (Reduce Soil Pollution and Erosion, 2016). The use of certain oil lubricants, paints, and wood preservatives as well as the weathering and corrosion of metals structures (e.g., galvanized metal roofs, wire fences, and pipes) also contributes to a pervasive background of both organic compounds and PTEs in soils in urban settings. Other contributions come from tire abrasion to increased metal loads in soils, particularly in the vicinity of high traffic areas. The use of chlorinated compounds such as chlorine used in the production of polyvinyl chloride (PVC) or tetrachloroethylene (TCE) use by the dry-cleaning industry, is also a cause of soil pollution e.g., by dioxins), (Genc,2015).

Oil spillage from leaking heating oil containers, gasoline station tanks and pipes, improper handling of oil wastes, and small accidental spills comprise most of the soil pollution by monoaromatic organic compounds including benzene, toluene, ethylbenzene, and xylene (often jointly called BTEX compounds). Although several man-made nitro aromatic compounds have been identified as toxic, carcinogenic, and persistent against degradation, their use in dyes, explosives, or as starting materials for pesticides and pharmaceuticals is common (Reduce Soil Pollution and Erosion, 2016).

Finally, pathogenic organisms, including pathogens excreted by humans and animals like Escherichia coli (E. coli) bacteria normally live in the intestines of healthy 
people and animals and others present in wastewater, sewage sludge, or manure applied to agricultural soils also contribute to soil pollution and can be most relevant sources for human soil-, water-, and food-borne diseases (Protect Wildlife, 2018).

To assess the degree of risks posed by such pollutants in soil, it is crucial to understand the major pathways by which such pollutants enter the soil (in order to reduce the load) and also to understand the (bio) chemical behaviour of such contaminants in order to assess their transfer into the food chain and impact on soil health if ingested via soil intake or otherwise.

\section{Electromagnetic radiation and its impact on the environment (Radioactive wastes)}

As the concentration of electromagnetic environment continues to increase, the concern about its effects from sources producing electromagnetic interference (EMI) also increases. Advances in technology and the number of hitech electronic products available are having a significant effect on the efforts aimed at maintaining the required operation and interoperability of products and systems used in our society (DiBiase, 2011).

Some sources of electromagnetic interference, both natural and man-made (anthropogenic), that generate electromagnetic emissions can be categorized into several primary groupings. Some of these groupings of electromagnetic radiation sources are listed below.

1. Television transmissions both analogue and digital

2. Radio AM, FM, and Satellite

3. Solar Magnetic Storms which peak on an eleven-year cycle

4. Lightning which occurs as a very high voltage and high current event

5. Utility power grid transmission lines which have high voltage, low current, and low frequency characteristics. In this category is also the new technology of Broadband over Power Lines (BPL) digital signals.

Other ambient electromagnetic emission sources include airport port radar, telecom transmissions, electrostatic discharge (ESD), and white noise. Also, in this category is the earth's magnetic field flux which has a value of about 500 milligauss. Some other major product and system's emissions sources include switching mode power supplies, arc welders, motor bushes, and electrical contacts.

\section{Noise pollution and its impact on the environment}

Closely related to interference is noise pollution which is an unwanted or disturbing sound which can interfere with normal activities for humans and wildlife, such as sleeping, conversation, reproduction, communication, or disrupt or diminish one's quality of life. Noise pollution can negatively impact the body in significant ways, including elevated blood pressure, impaired cognitive functioning, cardiovascular and psycho physiological effects, cause heart attacks, reduce performance, provoke annoyance responses and changes in social behaviour and other effects of chronic stress.

Noise pollution which is largely generated by man and his activities, can come from very many sources, such as automobiles, motorcycles, aircraft, ships, trucks, buses, jet planes, construction equipment, electrical machinery, lawn mowers and leaf blowers, to name a few. Excessive noise pollution, from the city streets to the oceans' commercial shipping traffic, can have harmful effects on the humans, plants, animals, trees and marine life constantly exposed to it (Hammer et al. 2014).

\section{SOLUTIONS TO ANTHROPOGENIC POLLUTION}

\section{Recycling}

One of the solutions to control anthropogenic pollution is by the process of recycling of wastes that constitute pollutants. Recycling is a process of converting waste materials into new products and objects. To promote the use of recycled products, recyclable materials can be processed, manufactured, labelled and marketed to support nature. Examples of recyclable products are plastics, metal cans, glass/bottle, paper, rubber, etc.

Recyclables also includes waste from old technologies, corrupt machines and defective machine which can be recycled as e-wastes. Functional parts of these old technologies can be re-used or repaired and parts which are completely defective can be recycled totally since most electronic parts are made of metals and plastic insulations (Brenner, 2018).

\section{Waste exchange}

In most industrial and production setups, some useless waste products generated by companies and organisations serve as needed raw materials in another. The reuse of these waste products in this instance serve to control environmental pollution as most of the reused wastes return to earth as enrichments or manure (Kumar, 2014).

\section{Afforestation}

One of the consequences of environmental pollution is desertification which can be combated through afforesta- 
tion. Afforestation is the process of establishing of forests or tree stands in areas which have been ravaged by desertification. Reduced primary forest harvest and high primary productivity make afforestation a highly efficient carbon sequestration (Khan, 2018).

\section{CONCLUSION}

In this paper, the consequences of anthropogenic pollution have been discussed with attention drawn on the potential harmful trace elements (PHTES). The paper has also proffered some recommendation that can help combat anthropogenic pollution.

Issues affecting the global environments are known to transcend beyond geographical boundaries and knows no language or culture. With threatening environmental issues like global warming, the world body should rally together to apply some control measure to it before the entire world is completely consumed by it. This could be done by controlling the amount of carbon dioxide and other greenhouse gas emissions into the atmosphere, especially by the developed economies of the world.

Again, the developed economies of the world should do more to stop discharging their industrial wastes into the seas to save aquatic and marine lives and preserve the seas and oceans. Also, the world body should find ways and means to limit, enforce and monitor radio-active emissions into the world environment. The recklessness with which these anthropogenic wastes are being discharge into the sea and underground calls for global concern. Radio-active wastes are another very dangerous element of the PHTEs that is ravaging the ecosystem due to increased industrialization and has the potential for unleashing far damaging effects to the world environment. The time for the world body to rise and do something is now.

\section{Recommendation}

To help combat the impact of anthropogenic pollution to the environment, the following recommendable steps are suggested:

1. Environmental education: In order to raise environmental consciousness and environmentally conscious individuals and ensure that such an environmentally conscious mindset is disseminated, there should be environmental education at all levels of life, for instance, at homes, school, etc.

2. Reforest the world: Deforestation should stop. Planting of trees should be encouraged, at least one fall tree, three new trees planted. Government should see to forest management and conservation (Reforest the World 2016).

3. Stop plastic pollution: Ending plastic pollution is about avoiding plastic in the first place and if unable to, reusing or recycling the material as opposed to tossing it into the garbage towards the landfill or onto the ground embarking it upon a journey to the sea.

4. Protect wildlife: If the present trend of wildlife extinction continues, within a few decades, at least half of all plant and animal species on earth will be extinct, as a result of climate change, habitat loss, pollution, etc.

\section{REFERENCES}

Alex, E. (2006). Chheang Icon Education. The child-nature Interaction. Stock exchange: Ezgi Bookstore.

Ana, U., Zuriñe A., Nora, U., M. A. G., \& Ramón J. B. (2012). Evaluation of the bioaccumulation of trace elements in tuna species by correlation analysis between their concentrations in muscle and first dorsal spine using microwave-assisted digestion and ICP-MS. International Journal of Environmental Analytical Chemistry, 92(15), 17611775.

Brenner, L. (2018) How can recycling help prevent pollution? Sciencing. Available at https://sciencing.com/can-recyclingprevent-pollution-7455182.html. Assessed Jun 2019

Commoner, B. (2016). Environmental pollution is an incurable disease: it can only be prevented. Available at https://conserve-energy-future.com/causes-and-effect-ofenvironmental-pollution.php. Assessed Jun 2019.

Demirbas, M., \& Pektas, H. M. (2009). Cogentin students chabang problem with associated basic concepts of reality doze negative education. Faculty of Electronics and Mathematics Training Magazine, 3(2), 195-211 (if exist, provide website link for this reference.

DiBiase, A. A. (2011). Electromagnetic interference sources and their most significant effects. Interference Technology. Available

https://interferencetechnology.com/electromagneticinterference-sources-and-their-most-significant-effects/\#

Espinoza, S. (2005). School raphaelites teacher candidates chheang friendly behaviour research [Investigation of Preservice Preschool Teachers' behaviours related to environmental awareness]. Hacettepe University Education Faculty Magazine, 28, 91-100.

Genc M., (2015). The project-based learning approach in environmental education. International Research in Geographical and Environmental Education, 24(2), 105-107.

Genc, M., Genc, T., Ergenc, M., \& Erkuz, N. (2016). Environmental problem perception of 6th grade students. World Journal of Environmental Research, 6(1) 14-24.

Gokmen, S. (2011). General Ecology. Ankara: Nobel Prize Academic Publishing.

Hammer, M. S., Swinburn, T. K., \& Neitzel, R. L. (2013). Environmental noise pollution in the United States: developing an effective public health response. Environmental Health Perspectives, 122(2), 115-119.

Hardoy, J. E., \& Satterthwaite, D. (1991). Environmental problems of Third World cities: a global issue ignored? Public Administration and Development, 11(4), 341-361.

Inyinbor, A., A., Adebesin, B., O., Abimbola, O., \& AdelaniAkande, T. A. (2018). Water pollution: effects, prevention, and climatic impact. Water Challenges of an Urbanizing World, 33 https://books.google.com.ng/books? $\mathrm{hl}=\mathrm{en} \& \mid \mathrm{r}=\& \mathrm{id}=4 \mathrm{WaQDwA}$ AQBAJ\&oi=fnd\&pg=PA33\&dq=Water+pollution:+effects+prev ention+and+climate+impact\&ots $=68 \mathrm{~B} 50 \mathrm{RrVIm} \& \mathrm{sig}=25 \mathrm{whj} 92$ 
P2ISiA8MsO3-nyr7nCeA\&redir_esc=y\#v=onepage\&q=Water \%20pollution\%3A\%20 effects\%20prevention\%20and\%20clim ate $\% 20$ impact\& $f=$ false.

Keinath, S. D. (2004). Environmental education and perceptions in eastern Nepal: Analysis of student drawings. Submitted in partial fulfilment of the requirements for the degree of Master of Science in Forestry Michigan Technological University.

Khan, F. (2018). Pollution - Causes and Effects | How to Control Pollution. Earth Reminder. Available https://www.earthreminder.com/pollution-causes-effectscontrol/\#HOW_TO_CONTROL_POLLUTION. Assessed May 6, 2019

Protect Wildlife (2018). Everything Connects. Available at http://www.everything connects.org/protect-wildlife.html. Assessed May 2018.

Reduce Soil Pollution and Erosion (2016). Everything connects. Available at http://www.everythingconnects.org/reduce-soilpollution.html.

Reduce Water Pollution (2016). Everything Connects. Available at http://www.everythingconnects.org/reduce-waterpollution.html.
Reforest the World (2016). Everything Connects. Available at http://www.everythingconnects.org/reforest-the-world.html.

Secgin, F., Yalvac, G., \& Cetin, T. (2010). Class Student Cartoons Rectilinear Problems, Iliskin Perceptions, International Conference on New Trends in Education and Their Implications, 11-13 November 2010, Antalya-Turkey, Pp. 391-398. Available at https://www.academia.edu. Assessed Jun. 2019.

Soykan, A., \& Atasoy, E. (2012). Historical development of nonformal environmental education in Turkey. Procedia-Social and Behavioral Sciences, 46, 736-743.

Steele, J. H., Thorpe, S. A, Turekian, K. K. (2008). Encyclopedia of ocean sciences. Elsevier ScienceDirect, Amsterdam. Available at https://www.worldcat.org/title/encyclopedia-ofocean-sciences/oclc/237028690.

Tuna, M. (2011). Environmental problems Kuresellesmesi. Social Sciences Institute Magazine, 1(2). 